\title{
HUBUNGAN PENGETAHUAN WANITA USIA SUBUR TENTANG KANKER SERVIKS DENGAN IVA TEST DI CIUMBULEUIT
}

\author{
Fifi Citra Wiryadi, Fitria Handayani \\ Poltekes TNI AU Ciumbuleuit \\ (fificitrawiryadi@gmail.com)
}

\begin{abstract}
ABSTRAK
Meningkatnya angka kejadian kanker serviks disebabkan oleh kurangnya pencegahan yang efektif dan deteksi dini. Kanker serviks telah menjadi masalah besar pada kesehatan perempuan karena selain menimbulkan kesakitan juga mengakibatkan banyak kematian. Global Burden Cancer (GLOBOCON) 2018, menunjukkan kejadian penyakit kanker di Indonesia sebanyak 136.2 per 100.000 penduduk. Penelitian ini bertujuan untuk mengetahui hubungan pengetahuan wanita usia subur tentang kanker serviks dengan IVA test di Ciumbuleuit. Metode Penelitian menggunakan analitik cross sectional, menggunakan kuesioner. Populasi dalam penelitian ini WUS yang berusia 18-49 tahun yang berdasarkan KTP sudah menikah dan berdomisili di RW 03 Kelurahan Ciumbuleuit. Berjumlah 848 dilakukan teknik pengambilan sampel menggunakan rumus slovin menjadi $(n=272)$. Hasil penelitian menunjukkan bahwa $80.5 \%$ responden belum pernah melakukan deteksi tes IVA. Hasil uji statistik menunjukkan ada hubungan yang signifikan antara pengetahuan wanita usia subur tentang kanker serviks dengan IVA test dengan $\mathrm{p}$ value $0,000<0.05$. Simpulan terdapat hubungan yang signifikan antara pengetahuan wanita usia subur tentang kanker serviks dengan IVA test.
\end{abstract}

Kata kunci: Kanker serviks, tes IVA, pengetahuan, wanita usia subur

\section{ABSTRACT}

The increasing incidence of cervical cancer is caused by the lack of effective prevention and early detection. Cervical cancer has become a major problem in women's health because in addition to causing pain, it also causes many deaths. Global Burden Cancer (GLOBOCON) 2018, shows the incidence of cancer in Indonesia is 136.2 per 100,000 population. This study aims to determine the relationship between knowledge of women of childbearing age about cervical cancer with the IVA test in Ciumbuleuit. The research method used cross sectional analytic, using a questionnaire. The population in this study WUS aged 18-49 years based on ID cards are married and domiciled in RW 03 Ciumbuleuit Village. A total of 848 samples were taken using the slovin formula to $(n=272)$. The results showed that $80.5 \%$ of respondents had never done the IVA test detection. The results of statistical tests showed that there was a significant relationship between knowledge of women of childbearing age about cervical cancer with the IVA test with a $p$ value of $0.000<0.05$. In conclusion, there is a significant relationship between knowledge of women of childbearing age about cervical cancer and the IVA test.

Keywords: Cervical cancer, IVA test, knowledge, women of childbearing age

\section{PENDAHULUAN}

Badan Kesehatan Dunia atau World Health Organization (WHO) menyebut kanker serviks sebagai jenis kanker nomor empat yang paling sering menyerang wanita dan mematikan 490.000 perempuan di dunia didiagnosa mengidap kanker serviks setiap tahunnya. Angka kematian kanker serviks yang tinggi banyak disebabkan karena keterlambatan dalam menemukan penyakit (WHO, 2018).

Menurut data Global Burden Cancer (GLOBOCON) 2018, menunjukkan 
kejadian penyakit kanker di Indonesia sebanyak 136.2 per 100.000 penduduk dan kasus baru kanker serviks di Indonesia mencapai 32.469 jiwa. Angka kematian akibat kanker serviks mencapai 18.279 per tahun. Ini artinya, ada sekitar 50 perempuan Indonesia meninggal dunia akibat kanker serviks. Angka itu melonjak tajam dibanding data GLOBOCON pada 2016 yang menyatakan 26 perempuan Indonesia meninggal karena kanker serviks setiap tahunnya (Rahayu, S. 2015).

Banyak upaya yang dilakukan dengan harapan dapat mencegah kanker serviks di masa mendatang dengan meningkatkan serapan vaksin HPV Perempuan dapat melakukan pemeriksaan dini kanker serviks upaya dalam upaya pencegahan penyakit tersebut dengan menggunakan pemeriksaan IVA Test, karena pada kasus pada kasus stadium I kanker serviks jarang terdeteksi. Pemeriksaan dengan menggunakan Inspeksi Pemeriksaan deteksi dini Visual Asam Asetat (IVA) merupakan skrining awal pemeriksaan kanker serviks yang cukup efisien dan efektif serta terbukti untuk menurunkan angka kanker serviks (Rahayu, S. 2015).

Pemahaman seseorang terhadap kanker serviks sangatlah penting. Beberapa faktor yang mempengaruhi pengetahuan salah satunya yaitu pengalaman, pendidikan, usia, pekerjaan, paritas, status dan jarak. Faktor-faktor tersebut merupakan penentu pengetahuan seseorang tentang kanker serviks yang dapat mempengaruhi sikap IVA Test. Pengetahuan yang baik terhadap deteksi dini kanker serviks akan membuat seseorang untuk bersikap mendukung untuk deteksi dini IVA Test (Restiyani, 2017).

Program deteksi dini ini dilakukan di setiap pelayanan kesehatan, cakupan pemeriksaan IVA sendiri masih rendah. Termasuk pemeriksaan IVA di wilayah Puskesmas Ciumbuleuit yang berada di Kecamatan Cidadap, Kota Bandung.

Wilayah kerja Puskesmas salah satunya adalah Kelurahan Ciumbuleuit yang terdiri dari $11 \mathrm{RW}$ dan 78 RT. Salah satu RW yang berada di Kelurahan Ciumbuleuit dengan jumlah wanita usia subur terbanyak berdomisili di RW 03 yang terdiri dari 9 RT.

Berdasarkan hasil studi pendahuluan yang telah dilakukan pada hari Senin tanggal 09 Desember 2019 di wilayah Kelurahan Ciumbuleuit dengan metode wawancara menanyakan pada 5 orang responden mengenai apa itu kanker serviks, bagaimana deteksi dini kanker serviks dan pernah atau tidak melakukan IVA Test. Dari pertanyaan yang dilakukan kepada 5 responden, 4 responden masih belum mengetahui tentang kanker serviks, cara mendeteksi dini kanker serviks, serta 5 responden tersebut belum pernah melakukan deteksi dini kanker serviks dengan metode IVA. 
Tujuan penelitian ini untuk mengetahui Hubungan pengetahuan wanita usia subur tentang kanker serviks dengan keikutsertaan IVA Test Kelurahan Ciumbuleuit.

\section{METODE PENELITIAN}

Studi analisis korelasi ini dilakukan dengan pendekatan Cross Sectional terhadap 272 wanita usia subur di RW 03 Kelurahan Ciumbuleuit. Pengumpulan data menggunakan data primer dan instrumen menggunakan kuesioner berisi pertanyaan untuk mengetahui pengetahuan kanker serviks dan keikutsertaan terhadap IVA Test.

Dalam penelitian ini digunakan uji chi kuadrat (chi square) untuk menentukan apakah terdapat hubungan antara pengetahuan wanita usia subur tentang kanker serviks dengan keikutsertaan IVA Test.

\section{HASIL DAN PEMBAHASAN}

Hasil penelitian yang didapatkan terhadap 272 wanita usia subur 18-49 tahun tentang hubungan pengetahuan wanita usia subur tentang kanker serviks dengan keikutsertaan IVA test di wilayah RW 03 Kelurahan Ciumbuleuit. Variabel yang diteliti dalam penelitian ini terdiri dari dua variabel yaitu pengetahuan wanita usia subur tentang kanker serviks dengan keikutsertaan IVA test.
Tabel 1. Distribusi Frekuensi Pengetahuan Wanita Usia Subur Tentang Kanker Serviks Di Wilayah RW 03 Kelurahan Ciumbuleuit.

\begin{tabular}{lcc}
\hline $\begin{array}{c}\text { Pengetahuan } \\
\text { Kanker } \\
\text { Serviks }\end{array}$ & $\begin{array}{c}\text { Frekuensi } \\
\text { (f) }\end{array}$ & $\begin{array}{c}\text { Persentase } \\
(\boldsymbol{\%})\end{array}$ \\
\hline Baik & 128 & 47 \\
Cukup & 106 & 39 \\
Kurang & 38 & 14 \\
\hline Total & $\mathbf{2 7 2}$ & $\mathbf{1 0 0}$ \\
\hline
\end{tabular}

bahwa pengetahuan wanita usia subur tentang kanker serviks pada penelitian ini yaitu, sebagian besar responden memiliki pengetahuan baik yaitu sebanyak 128 orang (47\%), berpengetahuan cukup sebanyak 106 orang (39\%) dan sebagian kecil responden sebanyak 38 orang (14\%) berpengetahuan kurang. Pengetahuan dipengaruhi oleh faktor lain yaitu sosial budaya dan ekonomi sehingga kebiasaan atau tradisi yang biasa dilakukan seseorang yang tidak melalui penalaran maupun baik atau buruknya. Status ekonomi juga akan mempengaruhi pengetahuan seseorang kemudian lingkungan, usia dan pengalaman berpengaruh terhadap proses masuknya pengetahuan ke dalam individu (Budiman R, 2013). 
Tabel 2. Distribusi Frekuensi Keikutsertaan IVA Test pada Wanita Usia Subur Di Wilayah RW 03 Kelurahan Ciumbuleuit.

\begin{tabular}{lcc}
\hline $\begin{array}{l}\text { Keikutsertaan } \\
\text { IVA Test }\end{array}$ & $\begin{array}{c}\text { Frekuensi } \\
(\mathbf{f})\end{array}$ & $\begin{array}{c}\text { Persentase } \\
(\boldsymbol{\%})\end{array}$ \\
\hline Tidak & 219 & 80.5 \\
Ya & 53 & 19.5 \\
\hline Total & $\mathbf{2 7 2}$ & $\mathbf{1 0 0}$ \\
\hline
\end{tabular}

Dari tabel 2 di atas dapat diketahui bahwa keikutsertaan pemeriksaan IVA sebagai upaya deteksi dini kanker serviks pada penelitian ini yaitu, sebagian besar responden yaitu 219 orang $(80.5 \%)$ responden tidak melakukan pemeriksaan IVA dan sebagian kecil responden yaitu sebanyak 53 orang (19.5\%) responden melakukan pemeriksaan IVA sebagai upaya deteksi dini kanker serviks. Dalam hal ini ada tiga faktor yang mempengaruhi perilaku yaitu faktor mempermudah (predisposing factor) yang mempengaruhi perilaku adalah sikap, pengetahuan, konsep diri, kepercayaan, nilai, dan informasi. Selain itu faktor seperti demografi misalnya status ekonomi, keluarga juga mempengaruhi perubahan perilaku. Faktor kedua Faktor pendukung (enabling factor) faktor ini menentukan keinginan terlaksana seperti sarana, prasarana, keahlian dan keterampilan. Sedangkan faktor ketiga adalah Faktor pendorong, faktor yang memperkuat perubahan perilaku seseorang dikarenakan adanya perilaku dan sikap orang lain seperti guru, keluarga, teman sebaya, dan lingkungan sekitar lainnya (Notoatmodjo, 2014) .

Tabel 3. Hubungan Pengetahuan Wanita Usia Subur Tentang Kanker Serviks Dengan Keikutsertaan IVA Test Di Wilayah RW 03 Kelurahan Ciumbuleuit

\begin{tabular}{llr}
\hline $\begin{array}{l}\text { Penge } \\
\text { tahuan }\end{array}$ & Keikutsertaan IVA Test & Nilai $p$ \\
Kanker & value \\
Serviks & & \\
\hline
\end{tabular}

\begin{tabular}{lccccccc}
\hline & \multicolumn{2}{c}{ Tidak } & & Ya & \multicolumn{3}{l}{ Total } \\
\hline & F & \% & F & \% & F & \% & \\
\hline Baik & 75 & 27.5 & 53 & 19.5 & 128 & 47 & \\
Cukup & 106 & 39.0 & 0 & 0 & 106 & 39 & 0,000 \\
Kurang & 38 & 14.0 & 0 & 0 & 38 & 14 & \\
\hline Total & $\mathbf{2 1 9}$ & $\mathbf{8 0 . 5}$ & $\mathbf{5 3}$ & $\mathbf{1 9 . 5}$ & $\mathbf{2 7 2}$ & $\mathbf{1 0 0}$ & \\
\hline \multicolumn{5}{c}{ Dari tabel 3} & dapat diketahui dari
\end{tabular}
jumlah populasi sebanyak 272 orang bahwa 128 responden yang memiliki pengetahuan baik tentang kanker serviks dengan melakukan keikutsertaan IVA test sebanyak 53 orang $(19.5 \%)$, tidak IVA test sebanyak 75 orang (27.5\%). Responden yang memiliki pengetahuan cukup sebanyak 106 orang (39\%) dan 38 orang (14\%) berpengetahuan kurang tidak ada yang melakukan pemeriksaan IVA test. Dengan nilai uji analisis chi-square 0,000 , yang menunjukkan ada hubungan antara pengetahuan WUS tentang kanker serviks dengan keikutsertaan pemeriksaan IVA. 
Penelitian ini sejalan dengan penelitian yang dilakukan oleh Dewi, dkk (2013) menyimpulkan bahwa ada hubungan positif yang signifikan antara tingkat pengetahuan WUS dengan pemeriksaan IVA. Semakin tinggi tingkat pengetahuan WUS, maka semakin tinggi perilaku pemeriksaan IVA.

Pengetahuan yaitu hasil dari penginderaan sesuatu terhadap suatu objek. Semakin tinggi tingkat pengetahuan seseorang, maka semakin baik kemampuan memahami informasi tentang deteksi dini kanker serviks, sehingga meningkatkan pengetahuannya tentang deteksi dini kanker serviks (Mubarak, 2007)

Sikap seseorang dipengaruhi oleh pengetahuan. Sikap berupa reaksi seseorang terhadap suatu objek. Pengetahuan sangat diperlukan untuk dapat memberikan informasi yang tepat terhadap perilaku seseorang. Pemahaman seseorang terhadap kanker serviks sangatlah penting. Seseorang yang memiliki pengetahuan tentang kanker serviks akan cenderung memiliki sikap yang baik terhadap pentingnya keikutsertaan mereka melakukan deteksi dini kanker serviks dengan pemeriksaan IVA (Septianingrum, 2017)

\section{KESIMPULAN DAN SARAN}

Simpulan penelitian ini terdapat hubungan yang bermakna antara pengetahuan tentang kanker serviks dengan keikutsertaan IVA test diwilayah RW 03 Kelurahan Ciumbuleuit.
Saran diperlukan suatu sosialisasi kepada Wanita Usia Subur (WUS) untuk mementingkan kesehatan reproduksi serta pentingnya dilakukan skrining pemeriksaan IVA.

\section{DAFTAR PUSTAKA}

Budiman, R. 2013. Kapita Selekta Kuesioner:Pengetahuan dan Sikap dalam Penelitian Kesehatan. Jakarta : Salemba Medika.

Dewi. 2013. Hubungan Tingkat Pengetahuan Wanita Usia Subur (WUS) dengan Pemeriksaan Inspeksi Visual Asetat (IVA) di Puskesmas Buleleng. Jurnal Magister Kedokteran Volume 1 No 1.

Mubarak. 2007. Promosi Kesehatan. Graha Ilmu. Yogyakarta.

Notoadmodjo, S. 2014. Metodologi Penelitian Kesehatan. Jakarta : Rineka Cipta

Rahayu, S. 2015. Asuhan Ibu dengan dengan Kanker Serviks. Jakarta : Salemba Medika

Restiyani. 2017. Hubungan karakteristik dan pengetahuan wanita usia subur tentang kanker serviks dan IVA dengan perilaku pemeriksaan IVA di wilayah kerja Puskesmas Krembangan Selatan Surabaya. Jurnal Universitas Airlangga

Septianingrum. 2017. Hubungan pengetahuan wanita usia subur tentang kanker serviks terhadap perilaku pemeriksaan IVA dijabarkan di Puskesmas Pisangan Cipatat Tanggerang Selatan

WHO 2018. Human Papillomavirus and Related Diseases Report : World 2018. HPV Centre. 